\title{
Gold Leaching by Various Solutions, Alternative of Cyanide and Their Prospects in the Future
}

\author{
Kholmahmad I. Kholov*a, \\ Nasim T. Sharifboev ${ }^{b}$, Shonavruz R. Samikhov ${ }^{a}$, \\ Sherzod R. Dzhurakulov ${ }^{a}$ and Mahjuba S. Zarifova ${ }^{a}$ \\ a.I. Nikitin Institute of Chemistry, Academy \\ of Sciences of the Republic of Tajikistan \\ Dushanbe, Republic of Tajikistan \\ ${ }^{b}$ Mining-metallurgy Institute of Tajikistan \\ Buston, Republic of Tajikistan
}

\begin{abstract}
The article discusses four alternative cyanide substitutes for the recovery of gold from ores and concentrates. Cyanide has been the premier gold leach reagent for over 100 years due to its high recovery, low cost and reliability. However, environmental damage from improper management has led to widespread research aimed at identifying and developing less toxic leaching agents. The article discusses the most widely researched cyanide substitutes, but it is clear that none of them has yet made any significant incursion into the dominance of cyanide as the preferred reagent in the vast majority of gold mines around the world.
\end{abstract}

Keywords: gold, leaching, cyanide, thiourea, thiosulfate, thiocyanate, halides. 


\title{
Выщелачивание золота различными растворами, заменители цианида и их перспективы в будущем
}

\author{
Х.И. Холов ${ }^{\text {, }}$ Н. Т. Шарифбоев ${ }^{0}$, \\ Ш.Р. Самихов ${ }^{\text {, Ш. Р. Джуракулов }}{ }^{\text {, }}$ М. С. Зарифова ${ }^{\mathrm{a}}$ \\ ${ }^{a}$ Институт химии имени В. И. Никитина НАН Таджикистана \\ Республика Таджикистан, Душанбе \\ бГорно-металлургический институт Таджикистан \\ Республика Таджикистан, Бустон
}

\begin{abstract}
Аннотация. В статье рассматриваются четыре альтернативных заменителя цианида для извлечения золота из руд и концентратов. Цианид был лучшим реагентом для выщелачивания золота, на протяжении более 100 лет, из-за его высокого извлечения, низкой стоимости и надежности. Однако ущерб, наносимый им окружающей среде в результате неправильного управления, привел к повсеместным исследованиям, направленным на выявление и разработку менее токсичных выщелачивающих реагентов. В статье рассматриваются наиболее широко исследованные заменители цианида, но очевидно, что ни один из них еще не внес значительных результатов в доминирующее положение цианида, как предпочтительного реагента на подавляющем большинстве золотых приисков по всему миру.
\end{abstract}

Ключевые слова: золото, выщелачивание, цианид, тиомочевина, тиосульфат, тиоцианат, галогениды.

Цитирование: Холов, Х.И. Выщелачивание золота различными растворами, заменители цианида и их перспективы в будущем / Х. И. Холов, Н. Т. Шарифбоев, Ш.Р. Самихов, Ш.Р. Джуракулов, М. С. Зарифова // Журн. Сиб. федер. ун-та. Техника и технологии, 2021, 14(4). C. 433-447. DOI: 10.17516/1999-494X-0324

\section{Введение}

Цианирование являлось преобладающим методом выщелачивания золота с тех пор, как оно было впервые предложено Джоном Стюартом Макартуром в 1880-х годах [1] из-за простоты процесса и низкой стоимости. Однако, к сожалению, цианид очень токсичен, и во всем мире произошло несколько серьезных экологических аварий, вызванных утечкой цианида с металлургических заводов [1-3]. Например, в Гайане около 2,9 млн м³ хвостов и сточных вод с примесью цианида было сброшено в результате обрушения дамбы хвостохранилища на руднике Омай в ночь на 19 августа 1995 года, что привело к загрязнению реки Омай. Подобная по масштабу катастрофа произошла 30 января 2000 года в Бая-Маре, Румынии, где была прорвана дамба хвостохранилища Aurul, в результате чего сточные воды, содержащие до 100 тонн цианида, попали в реку Дунай (см. дополнительные примеры и их последствия в табл. 1 и работе [4]).

Из-за экологических проблем выщелачивание цианида в настоящее время запрещено во многих регионах. Кроме того, период выщелачивания цианированием обычно составляет 24 часа [3], и золото не может быть эффективно выщелочено из упорных золотых руд. Таким образом, в последние годы все больше внимания уделяется альтернативным выщелачивателям золота. Среди этих выщелачивающих средств наибольшее внимание привлекли хлориды, тиомочевина и тиосульфат. Развитию хлоридного выщелачивания препятствуют в основном, 
Таблица 1. Примеры аварий на шахтах, связанных с цианидами, и их воздействия на окружающую среду

Table 1. Examples of cyanide-related mine accidents and their impact on the environment

\begin{tabular}{|c|l|l|l|}
\hline \multicolumn{2}{|c|}{ Шахта } & \multicolumn{1}{|c|}{ Место и дата } & \multicolumn{1}{|c|}{ Воздействия } \\
\hline 1. & $\begin{array}{l}\text { Шахта } \\
\text { Саммитвилля }\end{array}$ & $\begin{array}{l}\text { Колорадо, США, } \\
1992 \text { г. }\end{array}$ & $\begin{array}{l}\text { Вызвал серьезные экологические проблемы } \\
\text { на 17-мильном участке реки Аламоса }\end{array}$ \\
\hline 2. & $\begin{array}{l}\text { Рудник Зортман- } \\
\text { Ландуски }\end{array}$ & $\begin{array}{l}\text { Монтана, США, } \\
1997 \text { г. }\end{array}$ & $\begin{array}{l}\text { Сильное загрязнение грунтовых вод, существенная } \\
\text { гибель диких животных }\end{array}$ \\
\hline 3. & $\begin{array}{l}\text { Золотой рудник } \\
\text { Эхо Бэй Майнс }\end{array}$ & $\begin{array}{l}\text { Невада, США, } \\
1989 \text { и } 1990 \text { гг. }\end{array}$ & $\begin{array}{l}\text { Восемь утечек цианида за двухлетний период } \\
\text { выбросили в окружающую среду почти 900 фунтов } \\
\text { цианида }\end{array}$ \\
\hline 4. & Кумтор & $\begin{array}{l}\text { Кыргызстан, } \\
1998 \text { г. }\end{array}$ & $\begin{array}{l}\text { Почти две тонны цианида натрия случайно попали } \\
\text { в поверхностные воды }\end{array}$ \\
\hline 5. & Рудник Омай & Гайана, 1995 г. & $\begin{array}{l}\text { Сброс более 860 миллионов галлонов хвостов, } \\
\text { содержащих цианид, в крупную реку }\end{array}$ \\
\hline
\end{tabular}

опасная рабочая среда, плохая селективность реакции и высокие требования к защите оборудования от коррозии. Будущее выщелачивания тиомочевины не является привлекательным, поскольку потребление и цена тиомочевины высоки, и, кроме того, она является предполагаемым канцерогеном [2]. Выщелачивание тиосульфатом широко рассматривается, как наиболее многообещающий альтернативный метод из-за его пониженного риска для окружающей среды, высокой селективности реакции, низкой коррозионной активности выщелачивающего раствора, дешевых реагентов и т. д. [5].

\section{Разработки по замене цианида в производстве золота}

Основная проблема при разработке заменителей цианида заключается в обеспечении соответствия конкретных металлургических процессов, выбранных для извлечения золота и характеристикам руды. Альтернативные выщелачивающие средства должны быть [5]: селективными, нетоксичными, совместимы с последующими процессами восстановления, недорогими и пригодными для вторичной переработки.

В таблице 2 приведены дополнительные критерии, которые необходимо учитывать в отношении выщелачивателей золота [6].

На протяжении более ста лет цианид натрия был преобладающим реагентом для выщелачивания золота из-за его превосходных характеристик для выщелачивания большого разнообразия руд и относительно низкой стоимости [7]. Более того, несмотря на то, что цианид является потенциально смертельным ядом при проглатывании в высоких дозах, он не вызывает хронических проблем со здоровьем или окружающей средой, если присутствует в низких концентрациях [3]. Он широко распространен в природе, продуцируется широким кругом микроорганизмов и более чем 2500 видами растений в рамках их нормального метаболизма [7]. Низкие концентрации цианида, используемые при измельчении золота и кучном выщелачивании, быстро разлагаются: цианид далеко не так вреден, как другие природные токсины (например, столбняк, стрихнин $\mathrm{C}_{21} \mathrm{H}_{22} \mathrm{~N}_{2} \mathrm{O}_{2}$ ), потому что он легко превращается естественными физическими, химическими и биологическими процессами в менее токсичные или нетоксичные формы.

$$
-435-
$$


Таблица 2. Критерии, которые следует учитывать в отношении выщелачивателей золота

Table 2. Criteria to be considered for gold leachate

\begin{tabular}{|c|c|c|}
\hline \multicolumn{2}{|c|}{ Разделы критериев } & Виды критериев \\
\hline \multirow[t]{4}{*}{1.} & \multirow{4}{*}{$\begin{array}{l}\text { Экономические } \\
\text { показатели }\end{array}$} & Капитальные затраты \\
\hline & & Затраты на добычу \\
\hline & & Доступность \\
\hline & & Затраты на детоксикацию / переработку \\
\hline \multirow[t]{3}{*}{2.} & \multirow[t]{3}{*}{ Токсичность } & Выбросы \\
\hline & & Простота использования \\
\hline & & Влияние на экологию \\
\hline \multirow[t]{4}{*}{3.} & \multirow{4}{*}{$\begin{array}{l}\text { Применимость } \\
\text { процесса }\end{array}$} & Ограничения (тип руды, селективность, контроль, разделение и т. д.) \\
\hline & & Возможность вторичной переработки \\
\hline & & Детоксифицируемость \\
\hline & & Доступность в большом масштабе \\
\hline
\end{tabular}

Поэтому, основная задача при разработке подходящего заменителя цианида при обработке золота заключается в разработке столь же эффективного и разлагаемого реагента для выщелачивания, который не является стойким токсином окружающей среды. Поскольку скорость цианирования золота относительно низкая, отрасль занимается поиском более быстрых реакций выщелачивания золота, способных обеспечить высокие скорости извлечения металла. Несмотря на то, что были проведены исследования по разработке вероятных заменителей, обусловленные в основном экономическими соображениями, список эффективных вариантов ограничен, поскольку большинство из них относятся к упорным рудам и не поддаются простому цианидному выщелачиванию [7]. В последующем обсуждении рассматриваются наиболее многообещающие альтернативы.

\section{Обзор по тиомочевинному выщелачиванию золота}

Использование тиомочевины $\left(\mathrm{NH}_{2} \mathrm{CSNH}_{2}\right)$ в качестве выщелачивателя для извлечения золота показало большие перспективы. Тиомочевинный раствор в кислых условиях растворяет золото, образуя катионный комплекс, реакция протекает быстро и извлечение золота может достигать 99 \% [8]. Анодная реакция следует уравнению:

$$
\mathrm{Au}+2 \mathrm{CS}\left(\mathrm{NH}_{2}\right)_{2}=\mathrm{Au}\left(\mathrm{CS}\left[\mathrm{NH}_{2}\right]_{2}\right)^{2+}+\mathrm{e}^{-} \text {. }
$$

Реагент, однако, следует использовать в относительно ограниченных условиях, так как он термодинамически достаточно стабилен в кислых и нейтральных средах, но быстро разлагается в основных растворах [9]. Выщелачивание обычно проводят в диапазоне $\mathrm{pH}$ 1-2, и его успешное применение зависит от тщательной оптимизации и контроля $\mathrm{pH}$, окислительновосстановительного потенциала, концентрации тиомочевины и времени выщелачивания. В таблице 3 приведены критические параметры выщелачивания тиомочевины [10].

В ряде источников утверждается $[8,10,11]$, что работы советских ученых Плаксина и Кожуховой $[12,13]$ были пионерским исследованием в этой области, но потенциал тиомочевины

$$
-436-
$$


Таблица 3. Критические параметры выщелачивания золота

Table 3. Critical gold leaching parameters

\begin{tabular}{|c|c|}
\hline Параметры выщелачивания & Значения параметров выщелачивания \\
\hline $\mathrm{pH}:$ & 1.4 скорректированное соответственно H2SO4 \\
\hline Редокс-потенциал & Макс. 250 мВ и мин. 150 мВ \\
\hline Концентрация тиомочевины & 2 кг/ \\
\hline Потребление тиомочевины & $10-15$ минут \\
\hline Время выщелачивания & \\
\hline
\end{tabular}

для растворения золота был признан гораздо раньше. Мойром [9], который в 1906 г. опубликовал статью «Тиокарбамид - новый растворитель для золота» [14] были проведены эксперименты, в которых, он растворял кусочки сусального золота в растворах тиомочевины (тогда называемого тиокарбамидом). Он показал, что необходимы кислотные условия и что реакция протекает быстро в присутствии подходящих окислителей. Однако в то время цианид уже был признан предпочтительным реагентом для обработки золотых руд, и поэтому открытие Мойра осталось без внимания более полувека. Тиомочевина серьезно рассматривалась, как альтернатива цианиду, только в последние 20 лет [12]. Это привлекательный вариант для обработки упорных руд и флотационных концентратов, хотя есть надежда, что при дальнейших исследованиях он может быть применен для обработки руд с более низким содержанием золота [10].

Во всестороннем обзоре Самихов Ш. Р., Зинченко 3. А. и Бобомуродов О. М. [15] определили следующее о кинетике тиомочевины: использование иона трехвалентного железа в серной кислоте - наиболее эффективная система; скорость выщелачивания зависит от концентрации тиомочевины и окислителя; ион трехвалентного железа связывает тиомочевину в комплексах железо-тиомочевина; скорость растворения золота во многом определяется $\mathrm{pH}$.

Как правило, золото может быть извлечено из тиомочевины путем цементации (с использованием железного порошка или алюминия) или путем абсорбции на активированном угле, или электролитическим извлечением, или с помощью ионообменных смол. По сравнению с цианидом, тиомочевина имеет определенные преимущества, в том числе низкую чувствительность к основным металлам ( $\mathrm{Pb}, \mathrm{Cu}, \mathrm{Zn}, \mathrm{As})$; низкую чувствительность к остаточной сере в кальцинах; высокое извлечение золота из пиритовых и халькопиритовых концентратов; и удовлетворительное извлечение золота из углеродистых (упорных) руд [16]. Она также представляет меньшую угрозу для окружающей среды. Сама по себе тиомочевина имеет более низкую токсичность и более высокую скорость растворения золота и серебра, чем цианид [17]. Более того, при использовании цианида для обработки тугоплавких сульфидных золотосодержащих руд, которые были предварительно окислены для высвобождения золота, полученные высококислотные растворы необходимо нейтрализовать перед цианированием, тогда как тиомочевину можно использовать напрямую, поскольку выщелачивание золота происходит в кислых растворах [18].

Несмотря на доказанную эффективность тиомочевины в качестве реагента для выщелачивания золота [16, 19-21], существует еще несколько полномасштабных операций. Ее внедрению

$$
-437-
$$


препятствовали следующие три фактора [22]: она дороже цианида, ее потребление при обработке золота велико и стадия извлечения золота требует дальнейшего развития.

Расход реагентов чрезвычайно высок, поскольку тиомочевина легко окисляется в растворе и, как предполагает Тремблай и др. [23], высокие затраты, связанные с выщелачиванием, вероятно, обусловлены тем, что процесс получения тиомочевины все еще находится на начальной стадии. Предыдущие попытки внедрить этот реагент привели к чрезмерному потреблению и увеличению производственных затрат. Также растет озабоченность по поводу его воздействия на окружающую среду. Несмотря на заявления о том, что тиомочевина менее токсична, чем цианид, предполагается, что она является канцерогеном, поэтому к ней следует относиться с осторожностью [20].

Эффективность тиомочевины в качестве заменителя цианида подтверждена обширными экспериментальными работами. Как сообщает Гонен [24], с точки зрения ее применимости в качестве реагента для выщелачивания, Шульц первоначально утверждал в своей работе, что добавление диоксида серы во время выщелачивания тиомочевины предотвращает его химическое разложение, что приводит к снижению расхода реагента $[25,26]$. Автор предположил, что образование пузырьков диоксида серы во время выщелачивания тиомочевиной драгоценных металлов предотвращает разложение дисульфида формамидина, которое может привести к покрытию золотых поверхностей тонкодисперсной адгезивной серой - продуктом разложения.

Совсем недавно Ш.Р. Самихов и др. [27] провели дальнейшие лабораторные исследования для оценки возможности выщелачивания тиомочевиной. Золото извлекали из выщелачивающих растворов путем адсорбции на активированном угле; золото элюировали углем с использованием смесей вода/спирт, а окончательное извлечение золота из элюирующих растворов осуществляли электролитическим извлечением. Авторы сообщили об общем выходе золота $82 \%$ при низком расходе реагентов (исходя из $85 \%$ извлечения золота при комнатной температуре и 99 \% извлечения после фаз адсорбции, десорбции и электровыделения). Гоненом и др. [24] были проведены более конкретные исследования, которые изучали влияние тиомочевины и типа окислителя, $\mathrm{pH}$, времени перемешивания и размера частиц на извлечение золота из руды Гюмушане-Мастра (Gumushane-Mastra) в Турции. Было определено, что при коротком времени выщелачивания и низких значениях $\mathrm{pH}$ количество окислителя и расход тиомочевины уменьшаются. Экстракция золота 75 \% была достигнута с использованием частиц размером 150 меш при времени перемешивания в течение пяти часов.

Мирослав и др. [28] исследовали возможность извлечения тиомочевиной золота из медных шламов в Ковохуты Кромпачи (Kovohutny Krompachy), Словения. Авторы сообщили, что тиомочевина извлекала из остатков около 80 \% золота. Орги и Аталай [29] сообщили о схожих результатах. При попытке извлечь золото из золотоносной руды Каймаз (Аu 4 г/т) с использованием тиомочевины и сульфата железа (III) в качестве окислителя при комнатной температуре удалось получить 80 \% извлечения золота за шесть часов. Это вещество также оказалось успешным нетоксичным растворителем для золота в России [30].

Тиомочевина выщелачивает золото быстрее, чем цианид, и является менее токсичной; образует катионные комплексы; и может использоваться на рудах, устойчивых к цианиду, при кучном и подземном выщелачивании [31]. Однако, как объяснялось ранее, пробелы в иссле- 
дованиях и затраты препятствовали ее широкому внедрению в качестве выщелачивающего реагента в золотодобывающей промышленности. Стоимость может быть непомерной из-за необходимого количества реагента. Как указывают Лакост-Буше и др. [32], высокий расход тиомочевины и низкая скорость растворения объясняются ингибирующим покрытием серы на поверхности золотых частиц, образующимся из-за разложения тиомочевины. Однако было предложено, что добавление диоксида серы к выщелачивающим растворам могло бы регулировать окислительно-восстановительную пару между тиомочевиной и ее первым продуктом разложения - формамидинсульфидом, тем самым сводя образование серы к абсолютному минимуму.

Наиболее значительные коммерческие разработки с использованием тиомочевины, произведенные на сегодняшний день в западноевропейских странах, на сурьмяных рудниках Новой Англии в Новом Южном Уэльсе, Австралии, были введены в эксплуатацию в 1982 году. Как объясняет Сваминатан [31], из-за толерантности тиомочевины к стибниту, компания смогла извлечь 50-80 \% золота из стибнитового концентрата с использованием тиомочевинного выщелачивания с последующим извлечением золота на активированный уголь. Совсем недавно Лакост-Буше и др. [32] использовали тиомочевину для выщелачивания золота из руды, содержащей $0,4 \% \mathrm{Cu}$ и 5,6 г/т Аu, полученной на руднике Валь д'Ор (Val d'Or) в Квебеке. С использованием тиомочевины из расчета 3,9 г/т получали 89 \% извлеченного золота.

\section{Применение тиоцианата при выщелачивании золота}

В 1906 году Уайт [33] впервые продемонстрировал, что тиоцианат эффективно растворяет золото в присутствии подходящего окислителя; однако работа с этим реагентом не велась до тех пор, пока Флеминг вновь не продолжил данные исследования в 1986 году [34]. Как объясняют Барбоса и Монхемиус [35], выщелачивание золота тиоцианатом, если оно проводится при pH от 1 до 2, позволяет использовать железо (III) в качестве окислителя. Во время растворения золота тиоцианатом железа (III) $\mathrm{Fe}^{\mathrm{III}}$ восстанавливается до $\mathrm{Fe}^{\mathrm{II}}$ при окислении $\mathrm{SCN}^{-}$, образуя несколько промежуточных частиц, включая $(\mathrm{SCN})_{3}{ }^{-}$и $(\mathrm{SCN})_{2}$, которые могут как окислять, так и образовывать комплексное золото. В водных растворах подкисленный тиоцианат может растворять золото с образованием комплексов Аu (I) и $\mathrm{Au}$ (II) [44].

Что касается соответствующих исследований, Барбоса-Филхо и Монхемиус [35] описывают аспекты химии и термодинамики тиоцианата, а Бродхерст и Дю Пре [36] описывают видообразование системы золото-тиоцианат. В последующей экспериментальной работе, проведенной Барбоса-Филхо и Монхемиусом $[37,40]$ с растворами $\mathrm{Fe}^{\mathrm{III}}$-тиоцианата, который восстанавливается от $\mathrm{Fe}^{\mathrm{III}}$ до $\mathrm{Fe}^{\mathrm{II}}$ с окислением $\mathrm{SCN}^{-}$, было показано, что в результате реакции самовосстановления образуются оба иона $(\mathrm{SNC})_{3}{ }^{-}$и $(\mathrm{SNC})_{2}$, которые были фундаментальными в механизме тиоцианатного растворения золота. Авторы пришли к выводу, что тиоцианат является «эффективным выщелачивателем золота в кислых условиях, обеспечивающим скорость растворения, сравнимую со скоростью растворения, полученного с тиомочевиной, но при этом предлагая преимущество гораздо большей стабильности против окислительного разложения». Холмогоров и др. [41] извлекли более 95 \% золота из слабокислых растворов, извлекая тиоцианатные комплексы на углеродных адсорбентах и ионообменниках. Дальнейшие исследования 
были выполнены в лабораторном масштабе Монхемиусом и Боллом, которые использовали растворы тиоцианата, катализируемые йодом, для выщелачивания золотых руд, добытых в Доминиканской Республике [34]. Эти исследователи пришли к выводу, что использованная тиоцианатная система дала результаты, сопоставимые с результатами цианидной системы, и продемонстрировала значительно большую эффективность, чем тиомочевина.

\section{Выщелачивание тиосульфатом}

Тиосульфат $\left(\mathrm{S}_{2} \mathrm{O}_{3}{ }^{2-}\right)$, химикат, широко используемый в фотографии и в фармацевтической промышленности, также был предложен в качестве замены цианида. Как объясняет Кузугуденли [42], золото медленно растворяется в щелочном тиосульфате. Скорость растворения зависит от концентрации тиосульфата и растворенного кислорода, температуры процесса и может быть увеличена добавлением ионов меди [44]. Золото образует стабильный анионный комплекс с тиосульфатом в соответствии со следующей реакцией:

$$
2 \mathrm{Au}+0,5 \mathrm{O}_{2}+4 \mathrm{~S}_{2} \mathrm{O}_{3}^{2-}+\mathrm{H}_{2} \mathrm{O} \rightarrow 2 \mathrm{Au}\left(\mathrm{S}_{2} \mathrm{O}_{3}\right)_{2}^{3-}+2 \mathrm{OH}^{-} .
$$

Хотя комплекс тиосульфата золота после образования является довольно стабильным, необходимы щелочные условия, чтобы предотвратить разложение тиосульфата кислотой [31]. Как объясняет Эйлмор [43], процесс выщелачивания тиосульфата катализируется медью и имеет ряд преимуществ по сравнению с обычным процессом цианирования, несмотря на его медленную скорость. Приемлемые скорости выщелачивания золота с использованием тиосульфата достигаются в присутствии аммиака вместе с медью [44]. В последние годы этот реагент серьезно рассматривался, как потенциальный заменитель цианида, поскольку он обычно вызывает меньшее воздействие на окружающую среду: выщелачивание тиосульфата оказывает меньшее влияние на посторонние катионы и вызывает меньше опасений по поводу загрязнения $[45,46]$.

Использование тиосульфата в качестве выщелачивающего реагента при обработке золота было впервые предложено в начале 1900-х годов. Как объясняют Эйлмор и Мьюир [47], в процессе, известном как «Von Patera Process», золотые и серебряные руды, сначала подвергнутые хлорированному обжигу, выщелачивались тиосульфатом. Перед Второй мировой войной богатые серебром сульфидные руды в Южной Америке и руда мексиканского рудника ЛеКолорадо подвергались коммерческому выщелачиванию тиосульфатом после хлорирования $[48,49]$. В течение 1980-х годов процедура была усовершенствована, в первую очередь за счет добавления ионов меди и стабилизации тиосульфата путем добавления $\mathrm{SO}_{2}$ или бисульфита [45].

C тех пор было предпринято несколько многообещающих экспериментальных исследований $[50,51]$. Большая часть этих работ проводилась с комплексными рудами, содержащими медь, углеродистые руды или руды, содержащие высокие концентрации свинца, цинка или марганца. Например, Йен и др. [52] использовали умеренно тугоплавкую золотую руду, содержащую пирит и халькопирит, для определения возможности использования тиосульфата в качестве альтернативной технологии кучного выщелачивания. Авторы сообщают, что извлечение золота на уровне 72 \% было достигнуто за 50 дней. Горное управление США использовало статистические экспериментальные методы для определения возможности выщелачива-

$$
-440-
$$


ния тиосульфата. Извлечение золота до 62 \% достигалось при выщелачивании низкосортных углеродистых руд [53].

Ряд недавних исследований был направлен на разработку стратегий предварительной обработки с целью улучшения восстановления тиосульфатом. Балаз и др. [54] исследовали использование механически активированного флотационного концентрата из сложной медносвинцово-цинковой руды из Банска-Ходруса, Словакия. Механическая активация концентрата была достигнута ультратонким измельчением, и было доказано, что оно оказывает положительное влияние на скорость извлечения золота с использованием тиосульфата аммония в присутствии ионов меди. Авторы указывают, что 90 \% извлечение золота было достигнуто всего за несколько минут, по сравнению с 54 \% извлечением, достигнутым в эквивалентных условиях для необработанного концентрата. Ш.Р. Самихов и др. [55] сообщили, что губчатое золото чистотой 99,92 \% было произведено выщелачиванием тиосульфатом аммония, хотя было обнаружено, что добавление сульфата меди не только ускоряет скорость выщелачивания золота, но и увеличивает потребление тиосульфата. Панайотов [56] описывает схожие результаты, указав, что при использовании тиосульфата можно достичь 91 \% извлечения золота, если концентрат предварительно окислить. В коммерческой практике тиосульфат успешно использовался Компанией Ньюмонта (Newmont and Consolidated Empire Gold Inc.) при кучном выщелачивании золотой руды.

Основная проблема при выщелачивании тиосульфата - большой расход реагента при экстракции [54]. Более того, процесс обычно медленный, хотя приемлемые скорости выщелачивания могут быть достигнуты в присутствии аммиака с использованием меди (II) в качестве окислителя $[51,53]$. Тем не менее высокий расход реагентов делает большинство тиосульфатных систем в целом неэкономичными, несмотря на их потенциальные экологические преимущества. В настоящее время не существует простого и доступного метода извлечения золота из растворов тиосульфатного выщелачивания [10].

\section{Применение галогенидов в процессе выщелачивания}

Использование галогенидных (фтор, хлор, бром, йод и астат) систем для растворения золота предшествовало цианированию [57]. За исключением фтора и астата, все галогены были протестированы и/или использовались для извлечения золота [58]. До появления цианида хлор широко использовался в качестве выщелачивающего реагента для извлечения золота из кальцинов, руд и концентратов. Хлор может образовываться в суспензиях и растворах путем электролиза раствора $\mathrm{NaCl}$ или добавлением $\mathrm{MnO}_{2}$ к соляной кислоте [59]:

$$
\mathrm{MnO}_{2}+4 \mathrm{HCl} \rightarrow \mathrm{MnCl}_{2}+2 \mathrm{H}_{2} \mathrm{O}+\mathrm{Cl}_{2} .
$$

Золото быстро выщелачивается хлором при низком рН:

$$
2 \mathrm{Au}+3 \mathrm{Cl}_{2} \Leftrightarrow 2 \mathrm{AuCl}_{3} .
$$

Скорость хлорирования поддерживается низким $\mathrm{pH}$, высоким содержанием хлоридов и хлора, повышенными температурами и большой площадью поверхности руды $[60,61]$. Хотя растворение золота с хлором происходит значительно быстрее, чем с цианидом, низкие концентрации сульфидов или других реактивных компонентов в руде могут привести к чрезмерному расходу реагентов и восстановить $\mathrm{AuCl}_{4}^{-}$до металлического золота.

$$
-441-
$$


Было проведено несколько исследований для определения эффективности хлора $[58,60]$. Исторически $\mathrm{AuCl}_{4}{ }^{-}$извлекался из хлоридных выщелачивающих растворов в виде металлического золота путем естественного восстановления на углероде или древесном угле, после чего «загруженный» углерод сжигался для получения золота. Сегодня комплекс хлорида золота восстанавливается на активированном угле в виде металлического золота, что обычно приводит к потере золота в хвосты из-за истирания мелких частиц золота с поверхности частиц активированного угля. Однако извлечение хлорида золота труднее, чем извлечение цианида, по ряду причин:

- требуется специальное оборудование из нержавеющей стали и с резиновым покрытием, способное выдерживать сильные коррозионные кислотные и окислительные условия;

- газообразный хлор очень ядовит и должен содержаться в замкнутом цикле как в целях оптимального использования газа, так и во избежание любого риска для здоровья;

- хотя хлорирование применялось для предварительной обработки тугоплавких и углеродистых руд на нескольких заводах в Соединенных Штатах в 1980-х годах, с тех пор сообщалось о нескольких экспериментальных или демонстрационных исследованиях использования этих систем $[62,63]$.

Бром был впервые идентифицирован как потенциальный растворитель для золота в 1846 году; скорость выщелачивания золота увеличивается в присутствии протонного катиона [15]. Однако несмотря на то, что его давно признали мощным экстрагентом золота, его применение начало рассматриваться серьезно только недавно. Бром обладает рядом преимуществ, включая быструю экстракцию, нетоксичность и приспособляемость к широкому диапазону значений $\mathrm{pH}$.

Хотя высокая скорость растворения дает ему определенное преимущество перед цианидом, при использовании брома часто наблюдается высокий расход реагентов, и поскольку он может объединяться с другими элементарными частицами с образованием токсичных соединений, затраты на строительные материалы для выдерживания жестких условий и результирующее воздействие на здоровье может быть непомерным. Однако, как отмечает Тран и др. [63], система бромид-бром привлекает все большее внимание, особенно после того, как Корпорация Великих озер (Great Lakes Corporation) запатентовала процесс выщелачивания золота на основе брома, который основан на патентованном соединении дибром-диметилгидантоине (DBDMH).

Скорость выщелачивания золота в растворах йодида также намного выше, чем при цианировании. Несмотря на то, что комплексы йодида золота наиболее устойчивы в водных раствоpax (среди галогенов), йод по-прежнему недостаточно используется и недостаточно изучен как выщелачивающий агент золота. Во многом это связано с его стоимостью [64].

В настоящее время галогенидные системы имеют ограниченный потенциал в качестве заменителей цианида, который сам заменил выщелачивающие агенты, такие как хлор, в первую очередь. Как объясняет Тремблай [23], галогенидные системы в настоящее время ограничены аналитическими приложениями, где способность одновременного разрушения сульфидов и скорость растворения более важны, чем расход реагентов. Более того, галогенидные комплексы золота обычно нестабильны, и критики по-прежнему скептически относятся к их широкому использованию из-за значительного химического и технологического контроля, необходимого во время обработки для поддержания золота в растворе [64]. 


\section{Выводы}

В статье рассмотрены альтернативные заменители цианиду, агенты выщелачивания золота. Несмотря на то что в лабораторных масштабах были предприняты значительные исследования, оказалось, что большинство, если не все, из выявленных альтернативных агентов имеют ограничения, препятствующие их широкому применению в золотодобывающей промышленности. Например, применение тиомочевины, несмотря на то, что данная технология является проверенной и подходит для упорных руд, связана с высокими затратами на детоксикацию, имеет ограниченную возможность вторичного использования и отличается такими параметрами процесса, которые трудно контролировать. Тиосульфат обладает теми же преимуществами, но он очень нестабилен, а также требует высоких затрат на детоксикацию и имеет ограниченную возможность вторичной переработки. Тиоцианат, будучи более стабильным, чем два первых реагента, недостаточно изучен, поэтому необходимо преодолеть значительные препятствия, прежде чем его можно будет рассматривать, как жизнеспособную альтернативу цианиду. Наконец, галогениды, которые использовались в этом контексте в прошлом, трудны в обращении и контроле, а также являются дорогостоящими.

Несмотря на решительную оппозицию со стороны части экологического движения, цианид в золотодобывающей промышленности, если дальнейшие исследования и разработки не сделают один или несколько альтернативных выщелачиваний экономически конкурентоспособными, останется единственным практичным реагентом для выщелачивания в крупномасштабных процессах извлечения золота. Однако следует понимать, что большая часть возражений против использования цианида в горнодобывающей промышленности основана на относительно небольшом количестве широко разрекламированных инцидентов, связанных с загрязнением, большинство из которых были вызваны либо плохой конструкцией, либо неправильной работой по добыче золота. Процесс цианирования уже более века используется на золотых приисках по всему миру, что является неопровержимым доказательством того, что при хорошо спроектированных и должным образом управляемых операциях по добыче цианида, можно безопасно использовать его в качестве реагента для выщелачивания золота без значительного риска для жизни человека или окружающей среды.

\section{Список литературы / References}

[1] Muir D. M. A review of the selective leaching of gold from oxidised copper-gold ores with ammonia-cyanide and new insights for plant control and operation. Miner. Eng. 2011, 24, 576-582.

[2] Самихов Ш.Р., Зинченко 3. А., Бобохонов Б. А. Изучение кинетики процесса цианирования золотосодержащих руд Таджикистана. Известия НАHT, Отд. физ.-мат., геол. и техн. наук. 2012, № 1, 85-91 [Samikhov Sh.R., Zinchenko Z. A., Bobokhonov B. A. Study of the kinetics of the cyanidation process of gold-bearing ores in Tajikistan. Proceeding NANT, Department of Physics and Mathematics, chem., geol. and tech. sciences, 2012, № 1, 85-91 (In Russian)]

[3] Young C.A. Cyanide: Just the Facts, in Cyanide. Minerals and Materials Society, New Orleans. 2001, 99-114.

[4] Hilson G., Monhemius A. J. Alternatives to cyanide in the gold mining industry: What prospects for the future? J. Clean. Prod. 2006, 14, 1158-1167.

$$
-443-
$$


[3] Korte G., Coulston F. From Single-Substance Evaluation to Ecological Process Concept: The Dilemma of Processing Gold with Cyanide. Ecotoxicology and Environmental Safety, 1998, № 32, 96-101.

[4] Moran R. Cyanide Uncertainties: Observations on the Chemistry, Toxicity, and Analysis of Cyanide in Mining-Related Waters. MPC Issue Paper. Mineral Policy Center, Washington. № 1, 1998.

[5] Mine Action. Cyanide Alternatives: Alternatives for Cyanide in the Gold Mining Industry. Great Basin Mine Watch, Reno, 2000.

[6] Moran R. More Cyanide Uncertainties: Lessons from the Baia Mare, Romania, MPC Issue Paper, 2001, № 3 .

[7] Mosher J. B., Figueroa L. Biological Oxidation of Cyanide: A Viable Treatment Option for the Minerals Processing Industry? Minerals Engineering, 1996, 9(5), 573-581.

[8] Лодейщиков В.В. Шамис Л. А., Каковский И. А., Хмельницкая О. Д. Исследование кинетики растворения серебра в водных растворах тиомочевины. Известия ВУЗов. Цветная металлургия, 1975, № 2, 77-81 [Lodeyshchikov V. V. Shamis L. A., Kakovsky I. A., Khmelnitskaya O. D. Investigation of the kinetics of silver dissolution in aqueous solutions of thiourea. Izvestiya VUZov. Non-ferrous metallurgy, 1975, № 2, 77-81 (In Russian)]

[9] Groenwald T. Potential applications of thiourea in the processing of gold. Journal of the South African Institute of Mining and Metallurgy, 1977, № 77, 217-223.

[10] Haas L. A. Thiourea leaching of carbonaceous gold ores. Mining Eng., 1983, 462.

[11] Горностаева Т. Д., Хмельницкая О. Д., Панченко А. Ф., Лодейщиков В. В. Исследование тиомочевинных комплексов серебра в сернокислых растворах потенциометрическим методом. Журнал неорганической химии, 1986, № 31, 115-118 [Gornostaeva T. D., Khmelnitskaya O.D., Panchenko A.F., Lodeyshchikov V.V. Study of thiourea complexes of silver in sulfuric acid solutions by potentiometric method. Journal of Inorganic Chemistry, 1986, № 31, 115-118 (In Russian)]

[12] Пласкин И.Н., Кожухова М. Растворимость золота и серебра в тиомочевине. Доклад AH CCP, 1941, № 31, 671-674 [Plaskin I. N., Kozhukhova M. The solubility of gold and silver in thiourea. Dok. AS SSR, 1941, № 31, 671-674 (In Russian)]

[13] Пласкин И.Н., Кожухова М. Растворение золота и серебра в растворах тиомочевины. Сб. науч. труд. Инс. ивет. мет., 1960, № 33, 107 [Plaskin I. N., Kozhukhova M. Dissolution of gold and silver in solutions of thiourea. Sb. Nauch. Tr. Ins. Tsvt. Met., 1960, 33, 107 (In Russian)]

[14] Moir J. Thiocarbamide - a new solvent for gold. Journal of the Chem. Met. Mining Soc. S. Africa, 1906, 332-336.

[15] Самихов Ш.Р., Зинченко З.А., Бобомуродов О.М. Разработка технологии тиомочевинного выщелачивания золота и серебра из концентратов месторождения Чоре. Цветные металльы, 2014, № 2, 62-66 [Samikhov Sh.R., Zinchenko Z.A., Bobomurodov O.M. Development of technology for thiourea leaching of gold and silver from concentrates of the Chore deposit. Nonferrous metals, 2014, № 2, 62-66 (In Russian)]

[16] Ubaldini S., Fornari P., Massidda R., Abbruzzese C. An innovative thiourea gold leaching process. Hydrometallurgy, 1998, № 48, 113-124.

[17] Lee H. Y., Kim S. G., Oh J. K. Cementation behaviour of gold and silver onto Zn, Al, and Fe Powders from Acid Thiourea Solutions. Canadian Metallurgical Quarterly, 1997, № 36, 149-155.

[18] Schultz R. G. Thiourea leaching of precious metals. Erzmetall, 1986, № 39(2), 57-59. 
[19] Juarez C.M., Dutra A.J.B. Gold Electrowinning from Thiourea Solutions. Minerals Engineering, 2000, № 13 (10-11), 1083-1096.

[20] Chen C.K., Lung T.N., Wan C.C. Thiourea leaching cupriferous concentrate containing gold, Hydrometallurgy, 1982, № 5, 207-219.

[21] Панченко А.Ф., Бывальцев В.Я., Лодейщиков В.В. Тиокарбамидное выщелачивание золота из сурьмяных концентратов, Цветная металлургия, 1987, № 4, $27-29$ [Panchenko A.F., Byvaltsev V.Y., Lodeyshchikov V.V. Thiocarbamide leaching of gold from antimony concentrates, Nonferrous metallurgy, 1987, No. 4, 27-29 (In Russian)]

[22] Deng T.L., Liao M.X., Wang M.H., Chen Y.M., Belzile N. Enhancement of gold extraction from bioxidation residues using an acidic sodium sulphite-thiourea system. Minerals Engineering 2001, № 14 (2), 263-268.

[23] Tremblay L., Deschenes G. E., McMullen J., Lanouette M. International Journal of Mineral Processing, № 48, 225-244.

[24] Gonen N., Kekec K., Kizilkaya B., Yildirim M. Leaching of Gumushane-Mstra ore with thiourea, in Proceedings of the $7^{\text {th }}$ International Mineral Processing Symposium, Turkey, 1998, 561565 .

[25] Schultz R. G. New aspects of thiourea leaching of precious metals. Journal of Metals, 1984, № $36,62-65$.

[26] Лодейщиков В. В., Панченко А.Ф., Х Хмельницкая О.Д. Тиокарбамидное выщелачивание золотых и серебряных руд. Гидрометаллургия золота, Москва, 1980, 26-35 [Lodeyshchikov V.V., Panchenko A.F., Khmelnitskaya O.D. Thiocarbamide leaching of gold and silver ores. Hydrometallurgy of gold, Moscow, 1980, 26-35 (In Russian)]

[27] Самихов Ш.Р., Зинченко 3. А. Исследование и разработка технологии тиомочевинного выщелачивания благородных металлов из рудного сырья. Материалы Международной научно-практической конферениии «Передовые технологии на карьерах», Бишкек, 2012, 92-95 [Samikhov Sh.R. Research and development of technology for thiourea leaching of precious metals from ore raw materials. Materials of the International Scientific and Practical Conference «Advanced Technologies in Open Pits», Bishkek, 2012, 92-95 (In Russian)]

[28] Miroslav S., Magdalena S., Jarmila H. Thiourea in gold leaching from copper slimes, in Metallurgy East-West'97, Slovakia, 1997, 142-147.

[29] Orgui S., Atalay U. Gold extraction from Kaymaz gold ore by thiourea leaching, Proceedings of the XXI International Mineral Processing Congress, Rome, 2000, 22-28.

[30] Абрамов А.А. Технология извлечения золота из руд в России, Материаль 7-го Международного симпозиума по переработке полезных ископаемых, Турция, 1998, 503-508 [Abramov A. A. Technology of gold recovery from ores in Russia, Proceedings of the $7^{\text {th }}$ International Mineral Processing Symposium, Turkey, 1998, 503-508 (In Russian)]

[31] Swaminathan C., Pyke P., Johnston R.F. Reagent Trends in the Gold Extraction Industry. Minerals Engineering, 1993, № 6 (1), 1-16.

[32] Lacoste-Bouchet P., Deschenes G., Ghali E. Thiourea leaching of a copper-gold ore using statistic design. Hydrometallurgy, 1998, № 47, 189-203.

[33] White H. A. The solubility of gold in thiosulphates and thiocyanates. Journal of the Chemical, Metallurgical and Mining Society of South Africa, 1905, № 6, 109-111.

$$
-445-
$$


[34] Barbosa-Filho O., Monhemius A.J. Leaching of gold in thiocyanate solutions - Part 1: chemistry and thermodynamics. Transactions of the Institution of Mining and Metallurgy, 1994, № 103, 105-110.

[35] Fleming C. A. A process for simultaneous recovery of gold and uranium from South African ores, in Gold 100-Proceeding of the International Conference on Gold. Vol. 2: Extractive Metallurgy of Gold, South African Institution of Mining and Metallurgy, Johannesburg. 1986. 301-309.

[36] Broadhurst J.L., du Preez J.G.H. A thermodynamic study of the dissolution of gold in the acidic aqueous thiocyanate medium using iron(III) sulphate as an oxidant. Hydrometallurgy, 1993, № 32, 317-344.

[37] Barbosa-Filho O., Monhemius A.J. Iodine-thiocyanate leaching system for gold, in Hydrometallurgy'94, Institution of Mining and Metallurgy, UK, 1994, 425-440.

[38] Масленицкий Н. М., Ч Чугаев Л.В., Борбат В.Ф., Никитин М. В., Стрижко Л. С. Металлургия благородных металлов, Металлургия, 1987, 432 [Maslenitsky N.M., Chugaev L.V., Borbat V.F., Nikitin M.V., Strizhko L.S. Metallurgy of noble metals, Metallurgy, 1987, 432 (In Russian)]

[39] Barbosa-Filho O., Monhemius A. J. Leaching of gold in thiocyanate solutions - Part 2: redox processes in iron(III)-thiocyanate solutions. Transactions of the Institution of Mining and Metallurgy, 1994, № 103, 111-116.

[40] Barbosa-Filho O., Monhemius A. J. Leaching of gold in thiocyanate solutions - Part 3: rates and mechanism of gold dissolution. Transactions of the Institution of Mining and Metallurgy, 1994, № 103, 117-125.

[41] Холмогоров А. Г., Кононова О. Н., Пашков Г. Л., Кононов Ю. С. Тиоцианатные растворы в золотой технологии. Гидрометаллургия, 2002, № 64, 43-48 [Kholmogorov A. G., Kononova O. N., Pashkov G.L., Kononov Y.S. Thiocyanate solutions in gold technology. Hydrometallurgy, 2002, № 64, 43-48 (In Russian)

[42] Kuzugudenli O.E., Kantar C. Alternatives to gold recovery by cyanide leaching. Erc. Univ. Fen Bil. Derg, 1999, № 15 (1-2), 119-127.

[43] Aylmore M. G. Treatment of a Refractory Gold-Copper Sulphide Concentrate by Copper Ammoniacal Thiosulfate Leaching. Minerals Engineering, 2001, № 14(6), 615-637.

[44] Самихов Ш.Р., Зинченко 3. А. Изучение разработки технологии тиосульфатного выщелачивания золота, серебра и меди из руды и концентратов месторождения Тарор. Becmник ТНУ, 2016, № 1 (196), 160-165 [Samikhov Sh.R., Zinchenko Z. A. Study of the technology of thiosulfate leaching of gold, copper and copper from ore and concentrates of the Taror deposit. Bulletin TNU, 2016, № 1 (196), 160-165 (In Russian)]

[45] Abbruzzese C., Fornari P., Massidda R., Vegliò F., Ubaldini S. Thiosulphate leaching for gold hydrometallurgy. Hydrometallurgy, 1995, № 39, 265-276.

[46] Feng D., Van Deventer J. S.J. Leaching behaviour of sulphides in ammoniacal thiosulphate systems. Hydrometallurgy, 2002, № 63, 189-200.

[47] Alymore M. G., Muir D. M. Thiosulfate Leaching of Gold - A Review. Minerals Engineering, 2001, № 14(2), 135-174.

[48] Von Michaelis H. Thiosulfate leaching of gold and silver. Randol Phase IV Report, Randol International, Golden, Colorado, № 12, 158-164.

$$
-446-
$$


[49] Gelves G.A., Arias V.A., Pedraza J.E. Recovering of refractory gold using ammonium thiosulphate solutions, Clean Technology for the mining industry, University of Concepcion. 1996, 477-487.

[50] Wan R. Y. Importance of solution chemistry for thiosulphate leaching of gold, World Gold'97, Australian IMM, Victoria, 1997, 159-162.

[51] Navarro P., Vargas P.C., Villarroel A., Alguacil F. J. On the use of ammonical/ammonium thiosulfate for gold extraction from a concentrate. Hydrometallurgy. 2002, № 65, 37-42.

[52] Yen W.T., Guo H., Deschenes G. Development in percolation leaching with ammonium thiosulphate for gold extraction of a mild refractory ore, in Proceedings of a symposium held in San Diego, California, Minerals, Metals and Materials Society, Pennsylvania, 1999, 441-455.

[53] Langhans J.W., Blake B.D. Gold extraction from low grade carbonaceous ore using thiosulphate, Practical aspects of international management and processing, Society for Mining, Metallurgy and Exploration, Colorado, 1996, 85-96.

[54] Balaz P. Ficeriova J., Boldizarova E., Haber M., Jelen S., Kammel R. Thiosulphate leaching of gold from a mechanochemically pretreated complex sulphide concentrate, Proceedings of the XXI International Mineal Processing Congress, Rome, 2000, A6-74-A6-81.

[55] Самихов Ш.Р., Зинченко 3. А. Исследования процесса тиосульфатного выщелачивания золотых мышьяксодержащих руд месторождения Чоре. Доклад НАНT, 2014, № 2, 145-150 [Samikhov Sh.R., Zinchenko Z. A. Research of the thiosulfate leaching process of gold arsenic-bearing ores of the Chore deposit, Report NAST. 2014, № 2, 145-150 (In Russian)]

[56] Panayotov V. T. A technology for thiosulphate leaching of Au and Ag from pyrite concentrates, Proceedings of the $6^{\text {th }}$ international mineral processing symposium, A. A. Balkema, Rotterdam, 1996, $563-565$.

[57] Самихов Ш. Р., Зинченко 3. А. Кинетика процесса хлоридовозгонки концентрата месторождения Чоре. Вестник ТНУ, 2013, № 1 (106), 181-184 [Samikhov Sh.R., Zinchenko Z. A. Kinetics of the process of chloride sublimation of the Chore deposit concentrate. Bulletin TNU, 2013, № 1 (106), 181-184 (In Russian)]

[58] Ramadorai G. Use of chlorine in the processing of gold ores, Precious Metals 1993, International Precious Metals Institute, Pennsylvania, 1993, 265-279.

[59] Jena P. K., Brocchi E. A. Metal Extraction Through Chlorine Metallurgy. Mineral Processing and Extractive Metallurgy Review, № 16, 1997, 211-217.

[60] Ximing L., Jiajun K., Xinhui M., Bin L. Chlorine leaching of gold-bearing sulphide concentrate and its calcine. Hydrometallurgy, 1992, № 29, 205-215.

[61] Huff R. V., Boughman D. R. Chloride process for precious metals recovery, In Situ Recovery of Minerals II, New York, 1994, 657-664.

[62] Tan T., Davis A., Song J. Extraction of gold in halide media, Extractive Metallurgy of Gold and Base Metals, Australian Institute of Mining and Metallurgy, Victoria, 1992, 323-327.

[63] Tran T., Davis A. Fundamental aspects on the leaching of gold in halide media, in EPD Congress 1992, Minerals, Metals and Materials Society, USA, 1992, 99-113.

[64] Marsden J., House I. The Chemistry of Gold Extraction, E. Horwood Ltd., England, $1992,4-8$. 